\title{
LATE PLIOCENE AND QUATERNARY EURASIAN LOCUST INFESTATIONS IN THE CANARY ARCHIPELAGO
}

\author{
Meco, J. ${ }^{a}$, Muhs, D.R. ${ }^{b}$, Fontugne, M. ${ }^{c}$, Ramos, A.J. ${ }^{d}$, Lomoschitz, A. $^{e}$, Patterson, D. ${ }^{f}$
}

\author{
a Departamento de Biología, ULPGC, 35017 Las Palmas, Canary Islands, Spain \\ b US Geological Survey MS 980, Federal Center, Box 25046, Denver, CO 80225, United States \\ c Laboratoire des Sciences du Climat et de l'Environnement, LSCE, CNRS, 91198 Gif sur Yvette, France \\ d Estación Espacial SEAS Canarias, ULPGC, 35017 Las Palmas, Canary Islands, Spain \\ e Departamento de Ingeniería Civil, ULPGC, 35017 Las Palmas, Canary Islands, Spain \\ f ATA Services, 165 South Union Blvd. Suite 350, Denver, 80228 Colorado, United States
}

\begin{abstract}
The Canary Archipelago has long been a sensitive location to record climate changes of the past. Interbedded with its basalt lavas are marine deposits from the principal Pleistocene interglacials, as well as aeolian sands with intercalated palaeosols. The palaeosols contain African dust and innumerable relict egg pods of a temperate-region locust (cf. Dociostaurus maroccanus Thunberg 1815). New ecological and stratigraphical information reveals the geological history of locust plagues (or infestations) and their palaeoclimatic significance. Here, we show that the first arrival of the plagues to the Canary Islands from Africa took place near the end of the Pliocene, ca. 3Ma, and reappeared with immense strength during the middle Late Pleistocene preceding MIS (marine isotope stage) 11 (ca. 420ka), MIS 5.5 (ca. 125ka) and probably during other warm interglacials of the late Middle Pleistocene and the Late Pleistocene. During the Early Holocene, locust plagues may have coincided with a brief cool period in the current interglacial. Climatically, locust plagues on the Canaries are a link in the chain of full-glacial arid-cold climate (calcareous dunes), early interglacial arid-sub-humid climate (African dust inputs and locust plagues), peak interglacial warm-humid climate (marine deposits with Senegalese fauna), transitional aridtemperate climate (pedogenic calcretes), and again full-glacial arid-cold climate (calcareous dunes) oscillations. During the principal interglacials of the Pleistocene, the Canary Islands recorded the migrations of warm Senegalese marine faunas to the north, crossing latitudes in the Euro-African Atlantic. However, this northward marine faunal migration was preceded in the terrestrial realm by interglacial infestations of locusts. $\square$ Locust plagues, Canary Islands, Late Pliocene, Pleistocene, Holocene, palaeoclimatology.
\end{abstract}

